\title{
Comparative morphology of early stages of two Mediterranean Sarcophaga Meigen, 1826 (Diptera; Sarcophagidae) and a review of the feeding habits of Palaearctic species
}

\author{
Salima Pérez-Moreno, M. Angeles Marcos-García*, Santos Rojo \\ Instituto de la Biodiversidad (CIBIO), Universidad de Alicante, E-03080 Alicante, Spain
}

Received 8 May 2005; revised 29 July 2005; accepted 30 July 2005

Abstract

The third instar larva of Sarcophaga hirticrus Pandellé, 1896 and Sarcophaga javita (Peris, González-Mora and Mingo, 1998) are described and figured for the first. The use of scanning electron microscopy (SEM) has been demonstrated as an effective tool for determining differences at the specific level, and is here applied. The two species are distinguished from other Sarcophaga spp. and the principal diagnostic character states are illustrated and discussed. Comparative information on immature stages morphology of the described Palaearctic Sarcophaga species and its feeding habits are compiled and provided in a tabulated form.

(C) 2005 Elsevier Ltd. All rights reserved.

Keywords: Sarcophagidae; Immature stages; Larval morphology; Ultrastructure; Breeding habits

\section{Introduction}

The immature stages of the majority of dipterous families remain poorly known (Hennig, 1968). In the case of the Sarcophagidae relatively few papers have appeared dedicated to the larval morphology of the family (Aspoas, 1991; Ebejer, 2000; Kirk-Spriggs, 1999, 2000, 2003; Méndez and Pape, 2002; Zumpt, 1965). The larval stages of many species of Sarcophagidae are necrophagous and for this reason those species termed 'flesh-flies' are significant in forensic entomology, being second only to the Calliphoridae (Diptera) in terms of their usefulness. Precise knowledge and precise diagnoses of their immature stages therefore have a very practical application in estimating the postmortem interval (Sukontason et al., 2003; Wells et al., 2001). Other species of Sarcophaginae and Miltogramminae are predatory on invertebrates (e.g. other insects, snails, earthworms, scorpions, crabs, etc.) (Méndez and Pape, 2002; Pape, 1987), and several species have been reported

\footnotetext{
* Corresponding authorTel.: +34 965 903400; fax: +34965903815.

E-mail address: marcos@ua.es (M.A. Marcos-García).
}

0968-4328/\$ - see front matter (C) 2005 Elsevier Ltd. All rights reserved. doi:10.1016/j.micron.2005.07.013 as being parasitic in vertebrates (mammals, turtles) (Dahlem, 1991; Valle de Sales et al., 2004).

In some cases, detailed descriptions of larvae implicated in traumatic human myiasis (Colwell and O'Connor, 2000; Zumpt, 1965) or found infesting mummified human remains have been published (Sukontason et al., 2003), but in these cases the descriptions have not been attributed to any named species, as adults were not obtained. Therefore, the breeding habits should be related to morphological and taxonomic knowledge in order to improve biological and practical considerations.

Sarcophagids larvae are easily recognised at family and generic level, but are morphologically remarkably similar subgenerically and inter-specifically (Aspoas, 1991). The use of scanning electron microscopy (SEM) to observe and photograph the morphology of dipterous larvae has enabled observation of a suite of intra-specific differences (Colwell, 1989), and to characterise some aspects (pseudocephalon, spinules, anterior and posterior spiracles, spiracular setae, rim of spiracular atrium tubercles and sensilia) not easily resolved with light microscopy (Aspoas, 1991). For this reason Cantrell (1981), indicates that it is important to describe the number of papillae forming the anterior spiracles, the shape of the peritreme of the posterior spiracles and the cephalopharingeal skeleton. 
Pape et al. (2002) cite 73 species of the genus Sarcophaga as occurring in the Iberian Peninsula, but detailed morphological descriptions of larvae based on SEM have been published for only five of these, namely: Sarcophaga africa (Wiedemann, 1824) (as S. cruentata Meigen, 1826), Sarcophaga crassipalpis Macquart, 1838, Sarcophaga dux Thomson, 1869, Sarcophaga exuberans Pandellé, 1896 and Sarcophaga tibialis Macquart, 1851.

Sarcophaga hirticrus Pandellé, 1896 and Sarcophaga javita (Peris, González-Mora and Mingo, 1998) occur sympatrically in southern Spain, where they are relatively abundant. Both species have been occasionally collected together from the terrestrial snail Otala punctata (Müller, 1777) (Pérez-Moreno, 2004).

In this study, the 3rd instar larvae of S. hirticrus and $S$. javita are described for the first time. Numerous features of the 3rd instar larvae of the two species are examined by use of SEM, in order to determine the presence of morphological character states of potential taxonomic value.

A table is provided which compiles published information about described larvae of Sarcophaga species and feeding habits (Table 1).

\section{Materials and methods}

All larval stages of $S$. hirticrus and $S$. javita were obtained from a laboratory colony maintained over several generations under constant conditions of $25^{\circ} \mathrm{C}$ temperature and $70-85 \%$ relative humidity, and a photoperiod of $15: 9 \mathrm{~h}$ L:D. The colony was originated from field-collected material obtained in Mutxamel 30SYH203506 (Alicante, SE Spain) (Pérez-Moreno, 2004), during studies of the life cycle of these species. Adult flies of S. hirticrus were placed into rearing cages and provided with a diet of sugar, water and pig's liver. The liver provided the protein meal for adult female as well as a medium for larviposition. Larvae of $S$. hirticrus were placed on a bed of a fine sand to facilitate the pupation. Some of these puparia were left for $24 / 48 \mathrm{~h}$ in order to allow their sclerotisation before being killed by freezing. In the case of $S$. javita, alive snails were provided to the females in order to stimulate the larviposition. The larvae and pupae were extracted with the help of a hand needle of the snail's shell.

Third instar larvae were selected for preservation. These are distinguishable from larvae of other calyptrate families in that the majority of species possess three nearly vertical, parallel, posterior spiracular openings, usually not orientated toward the opening in the peritreme. For permanent preservation, larvae were killed by immersion in cold water and slowly boiled for approximately four minutes to distend them. Following this they were preserved in $70 \%$ alcohol.

Descriptions are based on preserved larvae and/or puparia. Cephalonpharyngeal skeletons attached by a membrane to the leading ventral edge of the interior of the puparia, were removed by immersion in water for approximately $24 \mathrm{~h}$ and were preserved in glycerine until use. Measurements were made using a graticule mounted in an eye piece of a binocular microscope.

Stereoscan micrographs were taken with SEM HITACHI S3000N operated at $20 \mathrm{kV}$. Specimens of immature stages of $S$. hirticrus and $S$. javita are deposited in the Entomological Collection of the University of Alicante (CIBIO).

The character states examined are as follows: the pseudocephalon, the cephalopharyngeal skeleton, the spinules, the anterior spiracles, the spiracular atrium and the posterior spiracles.

Taxonomic nomenclature in this paper follows Pape (1996). Larval terminology used in this paper follows Teskey (1981) and Courtney et al. (2000) for ventral organ.

\section{Results}

\subsection{Sarcophaga hirticrus Pandellé, 1896}

\subsubsection{Overall appearance (Fig. 1(A))}

Newly moulted larvae are creamy white in colour. Length $9.85 \pm 0.86 \mathrm{~mm}$, maximum width $3.63 \pm 0.31 \mathrm{~mm}$ $(n=10)$.

Larvae elongated, sub-cylindrical in cross-section with a flattened ventral surface, truncated posteriorly and tapering toward the anterior extreme.

Posterior surface of anal segment with a distinct cavity, which contains the posterior spiracles. The surface of thoracic and abdominal segments with bands of spinules of subtriangular form. The inter-band areas are devoid of spinules (Fig. 1(A)).

Anal segment with two postanal tubercles with apical sensillae. Surface of the postanal tubercles covered with spinules in the half basal part.

\subsubsection{Pseudocephalon (Fig. 1(B) and (C))}

The pseudocephalon has a pair of small antennae (a) and two palps (p) (Fig. 1(C)). Antennae appearing with two segments, the apical (dome) in conical shape. The palps are mammeliform, with concentric ribbons at the apical extreme where are placed five sesilla, the three posterior ones sited in the same protuberance and nominated maxillary palpus sensilla (mxpp).

At both sides of the mouth, between the inferior part of the palps and the maxilla, appear extensive bands of elongated, slightly corrugated overlapping oral ridges (or). Ventral organs (vo) present.

The strong maxillae $(\mathrm{m})$ are smooth, widely curved and retractable (Fig. 1B). Buccal cavity displays a pair of sensilium (Fig. 1(C)).

\subsubsection{Thorax (Fig. 1(D))}

The prothorax is rounded by spinules one or two pointed and grouped in a variable number. Anterior spiracles (as) 


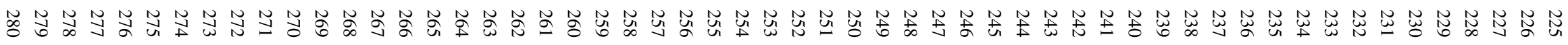
Table 1

Review of morphology of immature stages and feeding habits of Palaearctic Sarcophaga species

\begin{tabular}{|c|c|c|c|c|c|c|c|c|}
\hline Species & $\mathrm{T}$ & $\begin{array}{l}\text { No. of lobes anterior } \\
\text { spiracles (3rd instar) }\end{array}$ & Ecdysial scar & $\begin{array}{l}\text { Cephalopharingeal } \\
\text { skeleton description } \\
\text { (instar) }\end{array}$ & Material from & References & Host/feedind habits & \\
\hline $\begin{array}{l}\text { Sarcophaga aegyptica } \\
\text { Salem, } 1935\end{array}$ & LM & 14-15/single row & - & 2nd and 3rd instar & Spain & $\begin{array}{l}\text { Saloña Bordas and } \\
\text { Gonzalez-Mora, } 2005 \\
\text { (M\&F) }\end{array}$ & Necrophagous & \\
\hline $\begin{array}{l}\text { Sarcophaga africa } \\
\text { (Wiedemann, 1824) (= } \\
\text { S. cruentata Meigen, } \\
\text { 1826) }\end{array}$ & SEM & 11-13/single row & - & - & South Africa & $\begin{array}{l}\text { Aspoas, } 1991 \text { (M); } \\
\text { Zumpt, } 1965 \text { (F); Pape, } \\
1987 \text { (F); Berner, } 1973 \\
\text { (F) }\end{array}$ & $\begin{array}{l}\text { Myiasic, decomposing } \\
\text { matter, feces, dead } \\
\text { snails }\end{array}$ & \\
\hline $\begin{array}{l}\text { Sarcophaga alba } \\
\text { (Schiner, 1868) }\end{array}$ & LM & $9-12 /$ single row & - & 3rd instar & Japan & Ishijima, 1967 (M\&F) & Dead fish and mammals & \\
\hline $\begin{array}{l}\text { Sarcophaga albiceps } \\
\text { Meigen, } 1826\end{array}$ & LM & $32-38 /$ irregular rows & No & All instars & Kano et al., 1951 & Kano et al., 1951 (M) & $\begin{array}{l}\text { Dead animals, feces, } \\
\text { garbage }\end{array}$ & \\
\hline $\begin{array}{l}\text { Sarcophaga antilope } \\
\text { Bötther, } 1913\end{array}$ & LM & 46-52/irregular rows & No & $\begin{array}{l}\text { 3rd instar } \\
\text { 3rd instar }\end{array}$ & Japan & $\begin{array}{l}\text { Ishijima, } 1967 \text { (M\&F) } \\
\text { Ishijima, } 1967 \text { (M\&F) }\end{array}$ & $\begin{array}{l}\text { Flesh in laboratory, } \\
\text { parasite of moth }\end{array}$ & $\frac{5}{8}$ \\
\hline $\begin{array}{l}\text { Sarcophaga argyros- } \\
\text { toma Robineau-Des- } \\
\text { voidy, } 1830\end{array}$ & SEM & 10-11/single row & Yes & - & Egypt & $\begin{array}{l}\text { Awad et al., } 2003 \\
\text { (M\&F); Povolny and } \\
\text { Verves, } 1997 \text { (F) }\end{array}$ & $\begin{array}{l}\text { Myiasic, necrophagous, } \\
\text { parasitoids }\end{array}$ & $\frac{5}{3}$ \\
\hline $\begin{array}{l}\text { Sarcophaga caerules- } \\
\text { cens Zetterstedt, } 1838 \\
(=\text { Rovineauella sco- } \\
\text { paria (Pandelle,1896)) }\end{array}$ & LM & 48-54/irregular rows & No & 3rd instar & Japan & $\begin{array}{l}\text { Ishijima, } 1967 \text { (M); } \\
\text { Pape, } 1987(\mathrm{~F})\end{array}$ & $\begin{array}{l}\text { Necrophagous, car- } \\
\text { casses, predators of } \\
\text { lepidopterous pupae }\end{array}$ & 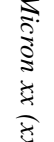 \\
\hline $\begin{array}{l}\text { Sarcophaga caudagalli } \\
\text { Böttcher, } 1912\end{array}$ & LM & $32-36$ & No & 3rd instar & Japan & Ishijima, 1967 (M\&F) & Chicken in laboratory & 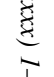 \\
\hline \multirow[t]{2}{*}{$\begin{array}{l}\text { Sarcophaga crassipal- } \\
\text { pis Macquart, } 1838\end{array}$} & LM & 9-14/single row & - & All instars & Japan & Kano et al., 1951 (M) & $\begin{array}{l}\text { Privies and animal car- } \\
\text { casses }\end{array}$ & $\frac{1}{N}$ \\
\hline & & $\begin{array}{l}9-14 / \text { single row } \\
11-12\end{array}$ & $\begin{array}{l}\text { No } \\
\text { Yes }\end{array}$ & $\begin{array}{l}\text { 3rd instar } \\
\text { All instars }\end{array}$ & $\begin{array}{l}\text { Japan } \\
\text { Australia }\end{array}$ & $\begin{array}{l}\text { Ishijima, } 1967 \text { (M\&F) } \\
\text { Cantrell, } 1981 \text { (M) }\end{array}$ & & \\
\hline $\begin{array}{l}\text { Sarcophaga dux Thom- } \\
\text { son, } 1869\end{array}$ & SEM & $14-17 /$ single row & - & All instars & Thailand & $\begin{array}{l}\text { Sukontason et al., } 2003 \\
\text { (M); Zumpt, } 1965 \text { (F) }\end{array}$ & Myiasic, carrion & \\
\hline $\begin{array}{l}\text { Sarcophaga exuberans } \\
\text { Pandellé,1896 }\end{array}$ & SEM & $8-10 /$ single row & - & - & South Africa & $\begin{array}{l}\text { Aspoas, } 1991(\mathrm{M}) \\
\text { Zumpt, } 1965(\mathrm{~F})\end{array}$ & Myiasic,carrion & \\
\hline $\begin{array}{l}\text { Sarcophaga harpax } \\
\text { Pandellé, } 1896\end{array}$ & LM & 40-44/irregular row & No & 3rd instar & Japan & Ishijima, 1967 (M\&F) & $\begin{array}{l}\text { Decaying animal mat- } \\
\text { ter, internal parasite }\end{array}$ & \\
\hline $\begin{array}{l}\text { Sarcophaga hirticrus } \\
\text { Pandellé, } 1896\end{array}$ & SEM & $7-10 /$ single row & Indistinct & 3rd instar & Spain & $\begin{array}{l}\text { New data (M\&F); Cas- } \\
\text { tillo, } 2001(\mathrm{~F}) ; \text { Blackith } \\
\text { et al., } 1997(\mathrm{~F})\end{array}$ & Carrion, snail and insect & \\
\hline $\begin{array}{l}\text { Sarcophaga horii Kano, } \\
1953\end{array}$ & LM & $34-37$ & No & 3rd instar & Japan & Ishijima, 1967 (M\&F) & Horseflesh in laboratory & \\
\hline $\begin{array}{l}\text { Sarcophaga inzi Curran, } \\
1934\end{array}$ & LM & $10 /$ single row & - & 3rd instar & Kalahari & $\begin{array}{l}\text { Kirk-Spriggs, } 1999 \\
(\mathrm{M \& F})\end{array}$ & $\begin{array}{l}\text { Dead millipedes } \\
\text { inued on next page) }\end{array}$ & \\
\hline
\end{tabular}




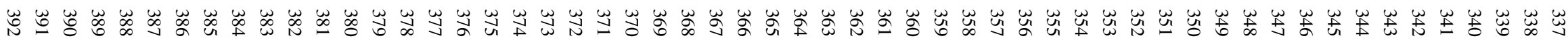

\section{Table 1 (continued)}

\begin{tabular}{|c|c|c|c|c|c|c|c|}
\hline Species & $\mathrm{T}$ & $\begin{array}{l}\text { No. of lobes anterior } \\
\text { spiracles (3rd instar) }\end{array}$ & Ecdysial scar & $\begin{array}{l}\text { Cephalopharingeal } \\
\text { skeleton description } \\
\text { (instar) }\end{array}$ & Material from & References & Host/feedind habits \\
\hline $\begin{array}{l}\text { Sarcophaga javita } \\
\text { (Peris, Gonzalez-Mora } \\
\text { \& Mingo, 1998) }\end{array}$ & SEM & 12-14/single row & Indistinct & 3rd instar & Spain & New data (M) & $\begin{array}{l}\text { Snail predator (unpub- } \\
\text { lished) }\end{array}$ \\
\hline $\begin{array}{l}\text { Sarcophaga kagaensis } \\
\text { Hori, } 1954\end{array}$ & LM & $34-38 /$ two rows & No & 3rd instar & Japan & Ishijima, 1967 (M\&F) & $\begin{array}{l}\text { Horseflesh and chicken } \\
\text { in laboratory }\end{array}$ \\
\hline $\begin{array}{l}\text { Sarcophaga kawayuen- } \\
\text { sis Kano, } 1950\end{array}$ & LM & 32-36/irregular rows & No & 3rd instar & Japan & Ishijima, 1967 (M\&F) & Dung, carcasses \\
\hline \multirow[t]{2}{*}{$\begin{array}{l}\text { Sarcophaga melanura } \\
\text { Meigen, } 1826\end{array}$} & LM & 12-15/single row & No & All instars & Japan & Kano et al., 1951 (M) & $\begin{array}{l}\text { Myiasic; birds and } \\
\text { mammals. Snails. } \\
\text { Feaces. }\end{array}$ \\
\hline & & 16-22/single row & & 3rd instar & & $\begin{array}{l}\text { Ishijima, } 1967 \text { (M\&F); } \\
\text { Seguy, } 1941(\mathrm{~F}) ; \\
\text { Blackith et al, } 1997 \text { (F) }\end{array}$ & \\
\hline $\begin{array}{l}\text { Sarcophaga misera } \\
\text { Walker,1849 }\end{array}$ & LM & 16-17/single row & No & 3rd instar & Japan & $\begin{array}{l}\text { Ishijima, 1967(M\&F); } \\
\text { Parashar and Rao, } 1988 \\
\text { (F); }\end{array}$ & $\begin{array}{l}\text { Human feces, carcasses, } \\
\text { dead fish, snails preda- } \\
\text { tor }\end{array}$ \\
\hline $\begin{array}{l}\text { Sarcophaga okazakii } \\
\text { Kano, } 1953\end{array}$ & LM & $38-43 /$ irregular rows & No & 3rd instar & Japan & Ishijima, 1967 (M\&F) & $\begin{array}{l}\text { Animal matter in lab- } \\
\text { oratory }\end{array}$ \\
\hline $\begin{array}{l}\text { Sarcophaga orchide }{ }^{\text {a }} \\
\text { Bötther, } 1913\end{array}$ & LM & $28-34 /$ two rows & No & 3rd instar & Japan & Ishijima, 1967 (M\&F) & $\begin{array}{l}\text { Human feces, dead ani- } \\
\text { mals }\end{array}$ \\
\hline \multirow[t]{2}{*}{$\begin{array}{l}\text { Sarcophaga peregrina } \\
\text { Robineau-Desvoidy, } \\
1830\end{array}$} & LM & 24-28/two rows & No & All instars & Japan & Kano et al., 1951 (M) & $\begin{array}{l}\text { Myiasic, necrophagous, } \\
\text { garbage, dead snails }\end{array}$ \\
\hline & & $\begin{array}{l}24-26 / \text { two rows } \\
28\end{array}$ & $\begin{array}{l}\text { No } \\
\text { Yes }\end{array}$ & $\begin{array}{l}\text { 3rd instar } \\
\text { All instars }\end{array}$ & Japan Australia & $\begin{array}{l}\text { Ishijima, } 1967 \text { (M\&F) } \\
\text { Cantrell, } 1981(\mathrm{M}) \text {; } \\
\text { Seguy, } 1941 \text { (F) }\end{array}$ & \\
\hline $\begin{array}{l}\text { Sarcophaga polystylata } \\
\text { Ho, } 1934\end{array}$ & LM & 14-16/single row & - & 3rd instar & Japan & Ishijima, 1967 (M\&F) & Dead animals \\
\hline $\begin{array}{l}\text { Sarcophaga pterygota } \\
\text { Thomas, } 1949\end{array}$ & LM & $24-28$ & No & 3rd instar & Japan & Ishijima, 1967(M\&F) & $\begin{array}{l}\text { Decaying animal mat- } \\
\text { ter, carcasses, garbage }\end{array}$ \\
\hline $\begin{array}{l}\text { Sarcophaga schuetzei } \\
\text { (Kramer,1909) }\end{array}$ & LM & $32-36$ & No & 3rd instar & Japan & Ishijima, 1967 (M\&F) & $\begin{array}{l}\text { Dead animals, parasites } \\
\text { of lepidopterous }\end{array}$ \\
\hline $\begin{array}{l}\text { Sarcophaga seniorwhi- } \\
\text { tei Ho,1938 (=Tricho- } \\
\text { lioproctia flavinervis } \\
\text { (Senior-White,1924)) }\end{array}$ & LM & 42-46/irregular rows & No & 3rd instar & Japan & Ishijima, 1967 (M\&F) & $\begin{array}{l}\text { Fish, chicken and } \\
\text { horseflesh in laboratory }\end{array}$ \\
\hline $\begin{array}{l}\text { Sarcophaga septentrio- } \\
\text { nalis (Rohdendorf, } \\
\text { 1937) }\end{array}$ & LM & $28-30 /$ two rows & No & 3rd instar & Japan & Ishijima, 1967 (M\&F) & Dead animals \\
\hline $\begin{array}{l}\text { Sarcophaga shirita- } \\
\text { kaensis Hori, } 1954\end{array}$ & LM & 46-49/irregular rows & No & 3rd instar & Japan & Ishijima, 1967 (M\&F) & $\begin{array}{l}\text { Animal matter in lab- } \\
\text { oratory }\end{array}$ \\
\hline \multirow[t]{2}{*}{$\begin{array}{l}\text { Sarcophaga similis } \\
\text { Meade, } 1876\end{array}$} & LM & $24-30 /$ two rows & No & All instars & Japan & Kano et al., 1951 (M) & $\begin{array}{l}\text { Carcasses, garbage, } \\
\text { feaces, intestinal } \\
\text { myiasis }\end{array}$ \\
\hline & & & & 3rd instar & & Ishijima, 1967 (M\&F) & \\
\hline
\end{tabular}




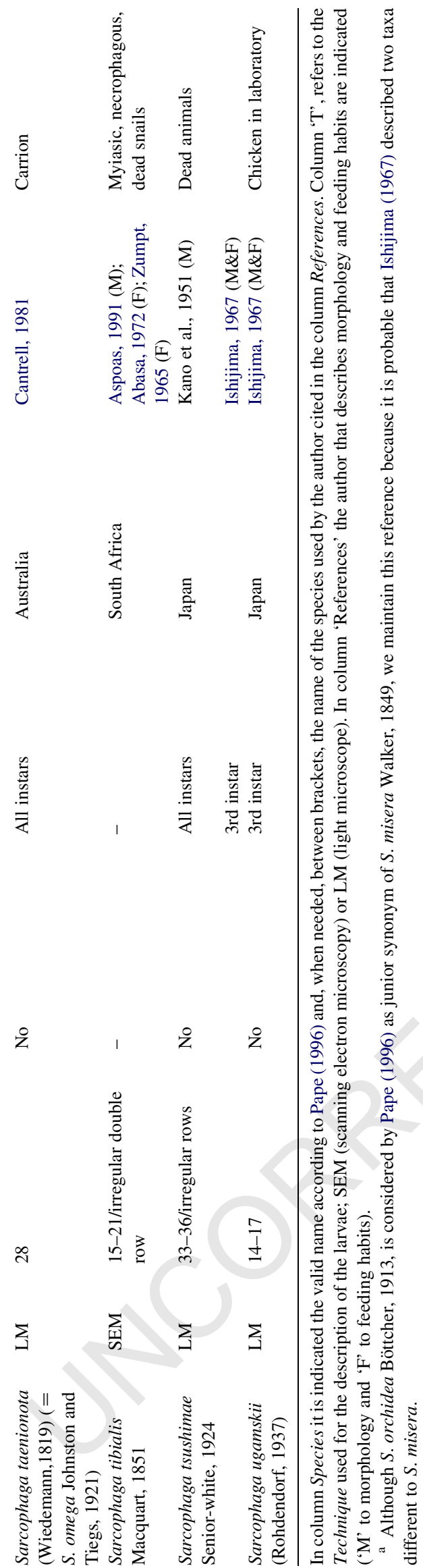

arising posterolaterally on the prothoracic segment and fanshaped (Fig. 1(D) pupa). Each anterior spiracle contains a single row of papillae that number from 7 to 10 .

The rest of the thoracic segments with an anterior band of spinules encircling each segment. These bands are constituted by seven crows of spinules without bifurcation.

\subsubsection{Abdomen (Fig.1(A), (E)-(G))}

Abdominal segments with anterior spinule bands. These bands encircle the segments. The inter-band areas are devoid of spinules.

The distribution of the abdominal spinule bands is different in dorsal and ventral position. In dorsal view the spinules are posteriorly projected and form one simple band, lacking spinules in the dorso-central area. These bands are wider towards the last body segment.

In ventral view, each band is constituted by three subbands of 3, 4-5, 3-4 rows of spinules alternately disposed. The spinules of the first subband are anteriorly projected and the spinules of the second and third subbands posteriorly. These spinules are one pointed (Fig. 1(E)).

In addition, there are rounded lateral areas in the spinules of the sides of the segments.

Abdominal segments display small fleshy protuberances laterally (Fig. 1(A)).

Posterior spiracles on the last eleventh body segment are set within a deep spiracular atrium (Fig. 1(G)). There are 12 tubercles $(\mathrm{t})$ located on the rim of the spiracular atrium (Fig. 1(F)). Spinules distributed around the rim and extending as far as the outer circumference of the ring formed by the tubercles.

Spiracles consisting of three elongate slits (s) oriented vertically, with the openings disposed radially, each surrounded by an incomplete sclerotized peritreme (p). Ecdysial scar indistinct. A branch of spiracular hairs (sh), constituted by a single trunk with $2-3$ branches, at both sides of the slits.

The anal segment displays two postannal tubercles whose surface is covered by spinules until the half. Each postanal tubercle has a sensilla in the apex.

\subsubsection{Cephalopharyngeal skeleton}

Mouthhook well developed (m); deeply pigmented, sickle-shaped, pointed in the apex and basally square. Dental sclerites (ds) present. Subhypostomal sclerite (ss) middle moon-shaped from above. Intermediate sclerite (hypopharyngeal sclerite, hs) short, wide with rounded anterior and posterior projections, $\mathrm{H}$-shaped from above and not fused to the basal sclerite. Pharyngeal sclerite (ps) relatively bulky and heavily pigmented at middle, with a parastomal bar (pb), slightly incurvated apically upwards. Dorsal cornu (dc) wider and longer than ventral cornu. Dorsal cornu with a narrow elongated window apically. Ventral cornu (vc) approximately twice longer than wide, apically subtruncated and with a small and dorsoapical oval 


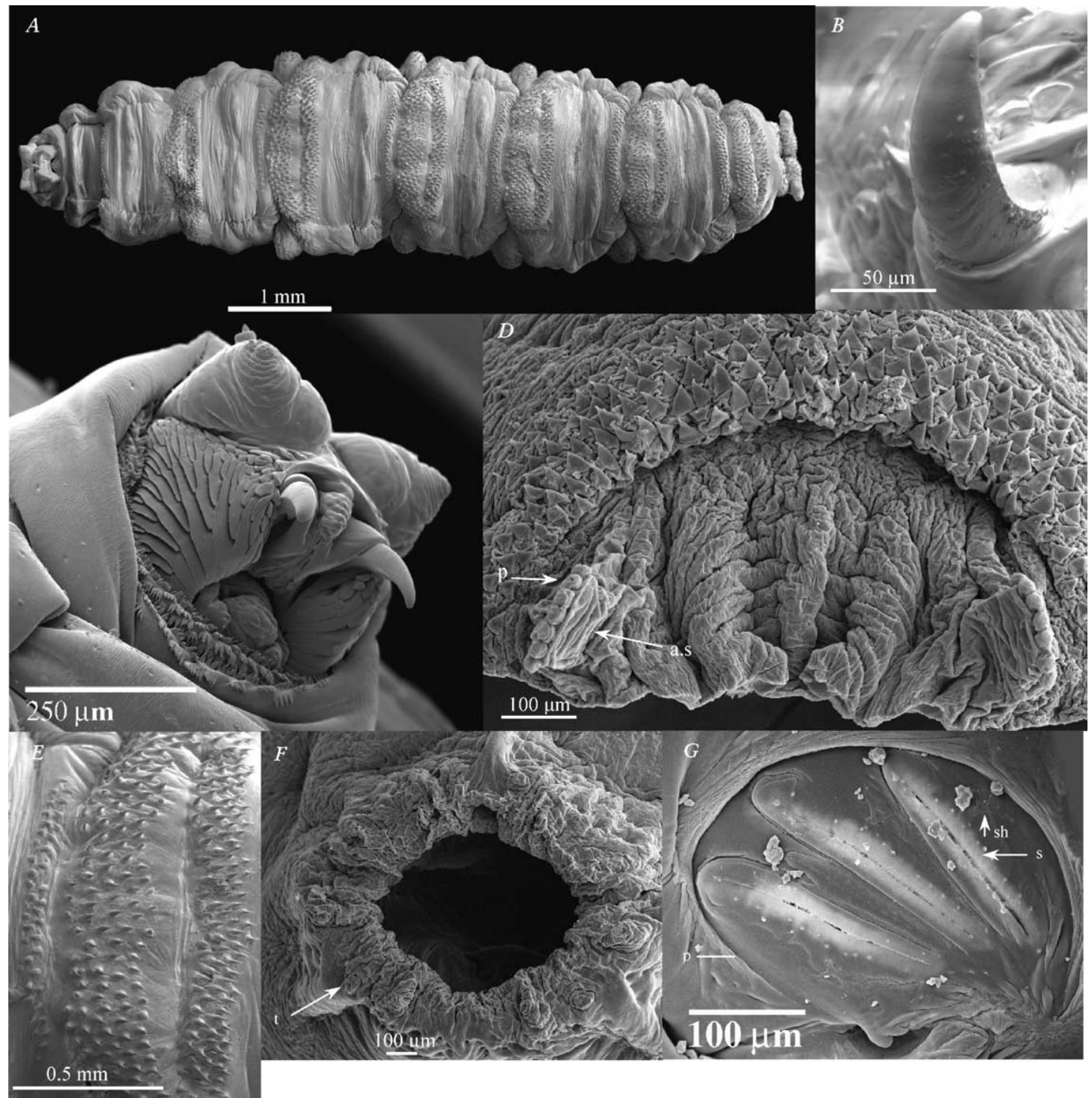

Fig. 1. Sarcophaga hirticrus. (A) general ventral view, (B) mouthhook, (C) pseudocephalon (a; antenna, or; oral ridges, p; palp, vo; ventral organ), (D) anterior spiracles (as, p; papillae) (puparium), (E) spinules, (F) spiracular atrium (puparium), (G) posterior spiracles (p; peritreme, s; slits, sh; spiracular hairs).

window. Dorsobasal lobe (dl) slightly marked near the apex of ventral cornu (Fig. 2).

\subsection{Sarcophaga javita (Peris, González-Mora and Mingo, 1998)}

\subsubsection{Overall appearance}

Length $11.46 \pm 1.73 \mathrm{~mm}$, maximum width $4.6 \pm$ $0.42 \mathrm{~mm}(n=10)$. Larvae are creamy white in colour, elongated, sub-cylindrical in cross-section with a flattened ventral surface, truncated posteriorly and tapering toward the anterior extreme.

The surface of thoracic and abdominal segments displays bands of spinules rounded in form. The inter-band areas are devoid of spinules.

\subsubsection{Pseudocephalon (Fig. 3(A), (B) and (D))}

The pseudocephalon has a pair of small antennae (a) in dorsal position and two palps (p) in inferior position (Fig. 3(A)).

The antennae are located in a depression and are formed by two segments, the apical (dome) sharpened at its end.

The palps are mammeliform, with concentric ribbons at the apical extreme. In the apical part there are three protuberance nominated maxillary palpus sensilla (mxpp) and exist two more situated at different levels (Fig. 3(D)). Ventral organs (vo) present.

At both sides of the mouth appear bands of little deep subparallel oral ridges (or). The base of the buccal cavity displays a pair of sensilium each of them with one setae and one hole (Fig. 3D).
656

657

658

659

660

661

662

663

664 


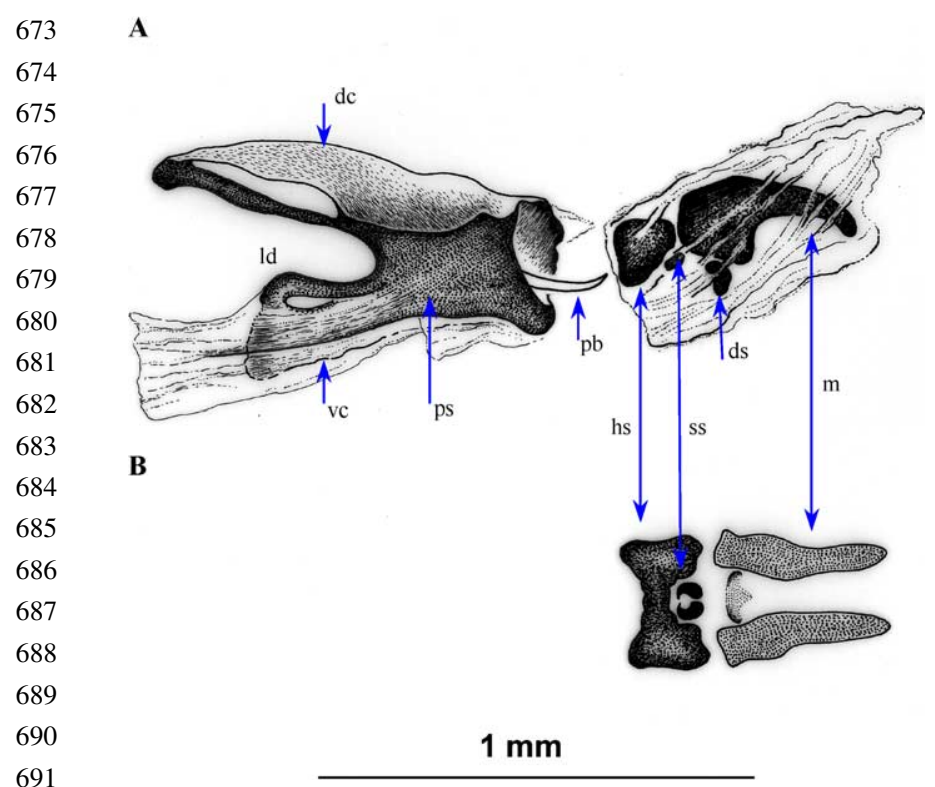

Fig. 2. Cephalopharyngeal skeleton of $S$. hirticrus ((A) lateral view, (B) dorsal view); $p b$ : parastomal bar, $d c$ : dorsal cornu, $v c$ : ventral cornu, $d s$ : dental sclerite, ps: pharyngeal sclerite, $h s$ : hypopharyngeal sclerite, ss: subhypostomal sclerite, $d l$ : dorsobasal lobe, $m$ : mouthhook.

\subsubsection{Thorax (Fig. 3(C), (E)-(G))}

The prothorax is anteriorly surrounded by a band of acute spinules (Fig. 3(C)), grouped in a variable number and some of them with two apical points. Anterior spiracles fanshaped. Each anterior spiracle contains a single row of papillae that number from 12 to 14 (Fig. 3(G)). The rest of the thoracic segments, with an anterior band of spinules encircling each segment. These spinules have a single end (Fig. 3(E) and (F)).

\subsubsection{Abdomen (Figs. 3(H), 4(A)-(D))}

Abdominal segments with anterior spinule bands one pointed and anteriorly projected. One of these bands narrower than the others and with the spinules posteriorly projected. Inter-band areas are devoid of spinules.

The posterior spiracles on the last eleventh body segment are set within a deep spiracular atrium. There are 12 tubercles (t) located on the rim of the atrium (Fig. 4(A)) each one with an apical setae (Fig. 4(D)). Spiracular atrium tapestried internally with spinules finished in a hook, sometimes grouped and none of them bifid (Fig. 4(C)). These spinules extended only as far as the inner circumference of the ring of tubercles. Posterior spiracles posterodorsal in the atrium, on a spiracular plate. Spiracles consisting of three elongate slits (s), oriented vertically, with the openings disposed radially, each with an incomplete sclerotized peritreme (p) (Fig. 3(H)). Ecdysial scar indistinct.

The anal segment (Fig. 4(B)) displays two postannals tubercles. The internal margin of these fleshy projections is covered with little sharp-pointed spinules. The apical stream of these fleshy projections shows a sensilia. A group of spinules appears at both sides of the insertion zone of the fleshy projections.

\subsubsection{Cephalopharyngeal skeleton}

Cephalopharyngeal skeleton deeply pigmented. Mouthhook (m) sickle-shaped, pointed apically. Dental sclerite (ds) present. Subhypostomal sclerite (ss) middle moonshaped from above. Intermediate sclerite (hypopharyngeal sclerite, hs) short, longer than wide, $\mathrm{H}$-shaped from above and not fused to the basal sclerite, with anterior arms tapering apically. Pharyngeal sclerite (ps) heavily pigmented with a pointed parastomal bar (pb). Extreme of pharyngeal sclerite incurved downwards. Dorsal cornu (dc) wider and longer than ventral cornu. Dorsal cornu with a narrow elongated apical window and opened in the apical extreme. Ventral cornu (vc) approximately twice longer than wide and apically truncated. Window reduced to a small split dorso-apically. Dorsobasal lobe (dl) slightly marked near the apex of ventral cornu (Fig. 5).

\section{Discussion}

Within the Sarcophagidae, larvae of some species of the genera Oxysarcodexia and Ravinia (Lopes and Leite, 1987), Sarcophaga (Aspoas, 1991; Kirk-Spriggs, 1999, 2000, 2003; Sukontason et al., 2003) and Wohlfahrtia (Ruiz-Martínez et al., 1989), have been described using of SEM. The increase of this kind of study is a consequence that the knowledge of the morphology of the immature stages receiving more attention due to their use in medico-forensic entomology.

The larvae of the two species described here, possess the morphological character states defined by Dahlem (1991) for the Sarcophagidae: 'deeply recessed posterior spiracles, mature larvae having three nearly vertical, parallel posterior spiracular slits arising from a ventral ecdysial scar (which is frequently indistinct or absent) and by the spiracular slits usually not pointing toward the opening in the peritreme'.

The cephalopharingeal skeleton is very similar in the two species studied as it is common in other saprophagous diptera (Rotheray and Gilbert, 1999), but there are some differences. The mouthhooks of $S$. hirticrus are proportionally larger and more curved than those in S. javita. Other authors have noted a limit in the mouthhooks retraction into the cephalic segment in other species such as Wohlfahrtia magnifica (Ruiz-Martínez et al., 1990). This character state should be analysed in other Sarcophaga species.

In $S$. hirticrus the ventral cornu of the basal sclerite has a small window, which is reduced to a small split in S. javita, whereas the parastomal bar is straighter in $S$. javita.

The presence of a central hook, as in W. magnifica, is possibly consistent with their parasitic nature (Ruiz-Martínez, 1990). It should also be interesting to describe the surface, ornamentation, shape and size of the mouthhooks in 

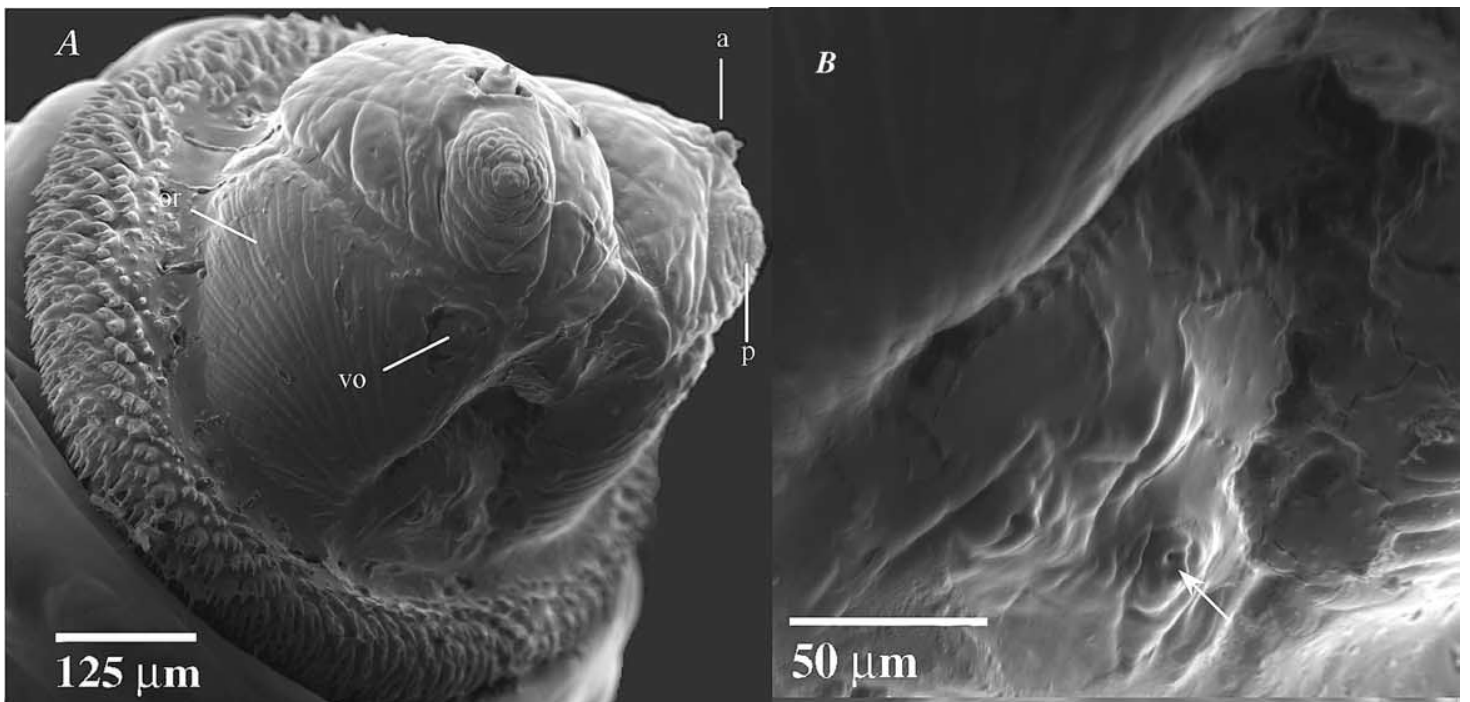

\section{$125 \mu \mathrm{m}$}
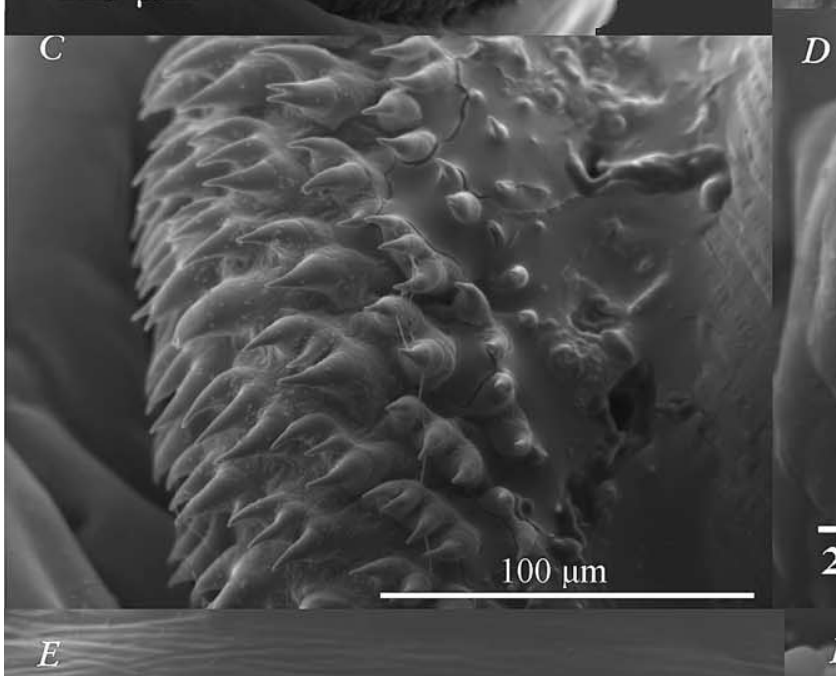

D
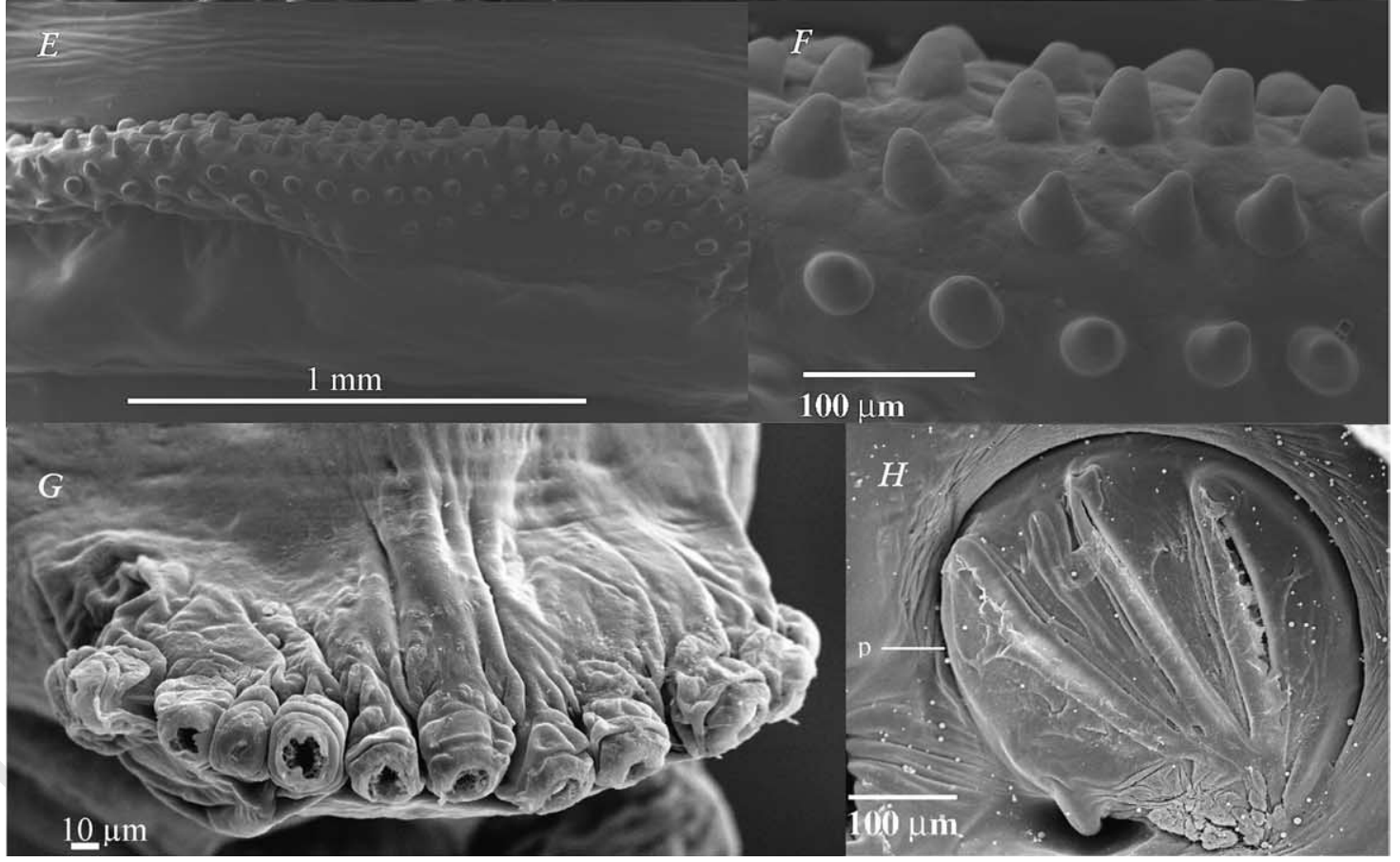

Fig. 3. S. javita. Pseudocephalon: (A) general view ( $a$; antenna, or; oral ridges, $p$; palp, vo; ventral organ), (B) oral cavity amplified, (C) prothoracic spinules, (D) palp (mxpp; maxillary palpus sensilla). Thorax: (E) dorsal spinules, (F) spinules amplified, $(\mathrm{G})$ anterior spiracle, $(\mathrm{H})$ posterior spiracle (p; peritreme). 


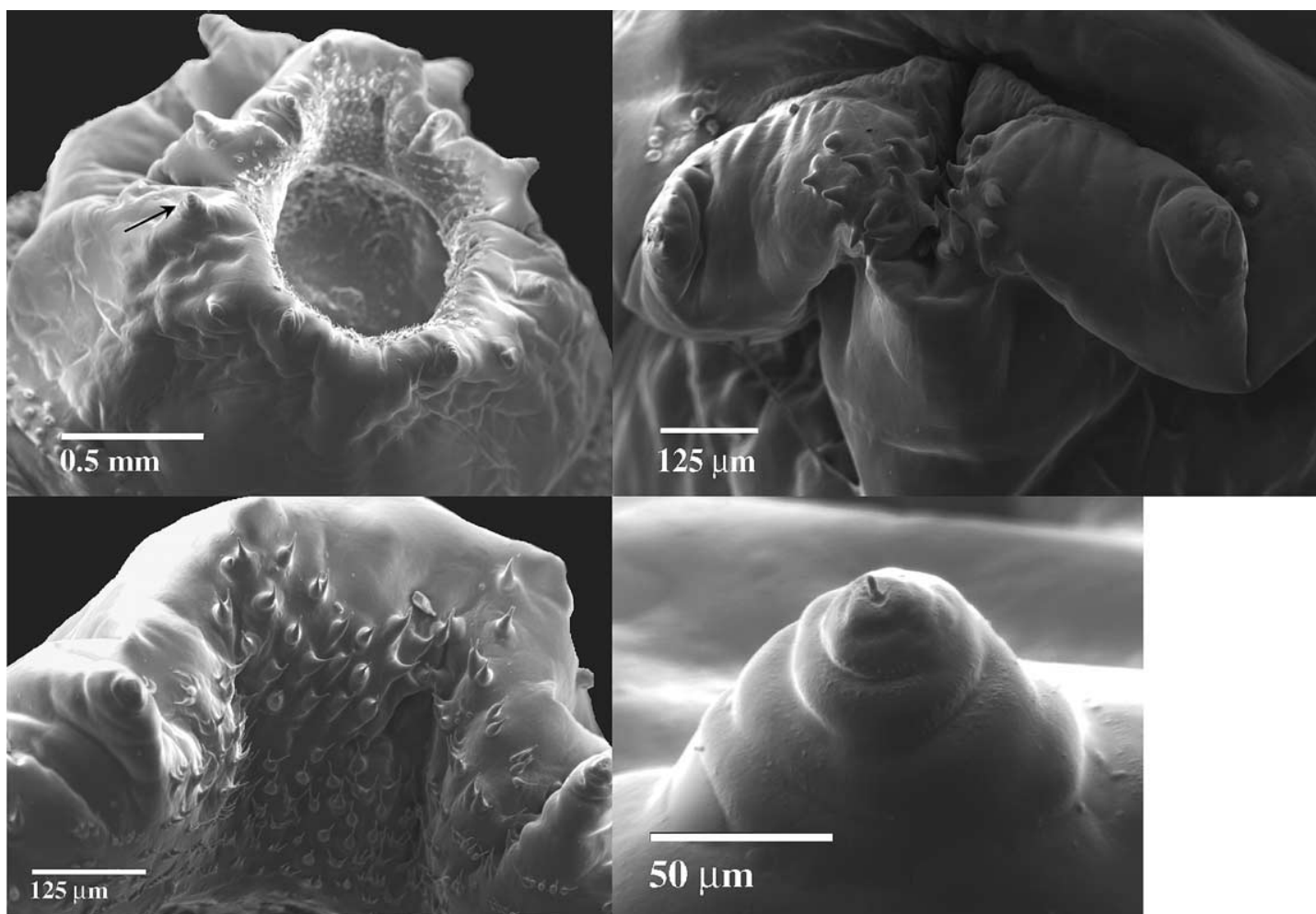

Fig. 4. S. javita. (A) tubercles of external border of the spiracular atrium, (B) postanal tubercles (C) internal atrium spinules, (D) tubercle amplified showing a setae.

detail in order to establish their possible relationship with feeding habits. In this sense Wohlfahrtia magnifica (Schiner, 1862), S. dux, Sarcophaga argyrostoma Robineau-Desvoidy, 1830 and $S$. hirticrus have an inferior cutting margin of the mouthhook (Ruiz-Martínez, 1990; Sukontason et al., 2003; Awad et al., 2003) in order to assist its penetration into carrion or wounds of animals, whereas Ravinia belforti show a mouthhook with delicate pits and ridges (Leite and Souza, 1987).

In the pseudocephalon of $S$. hirticrus, the palps and the antennae, are situated on a conical prominence. This morphology is also appreciated in other species such as Sarcophaga forceps Blackith and Blackith, 1988 (Kirk-Spriggs, 2000), however, this prominence is less pronounced in S. javita. Bearing in mind the differences found in the pseudocefalon of the species of Sarcophagidae, it would be interesting to illustrate this segment from the same angle always in order to facilitate comparison between species.

Although the morphology of the pseudocephalon has not usually been considered, according to Kirk-Spriggs (2003), the disposition and morphology of the oral ridges of the two species here described seem to be useful inter-specific character states.

The number of papillae in the anterior spiracles of these two species at L3 instar (7-14) is similar to that of other species of the same genera such as Sarcophaga melanura, $S$. crassipalpis, Sarcophaga africa, Sarcophaga iota (Johnston and Tiegs, 1921), S. dux, Sarcophaga nodosa Engel, 1925, Sarcophaga inzi Curran, 1934, and in species of other genera such as Wohlfahrtia virgil (Walker, 1849) and Oxysarcodexia confusa Lopes, 1946 (Leite and Lopes, 1987; Walker, 1920). This indicates that the exclusive use of this criterion is insufficient for a correct identification of the larvae, even at generic level. Kano and Sato (1951), indicate in Sarcophaga a slight variability in the number of papillae between individuals or even on each side of the same pupae. This variability also occurs in other genera such as

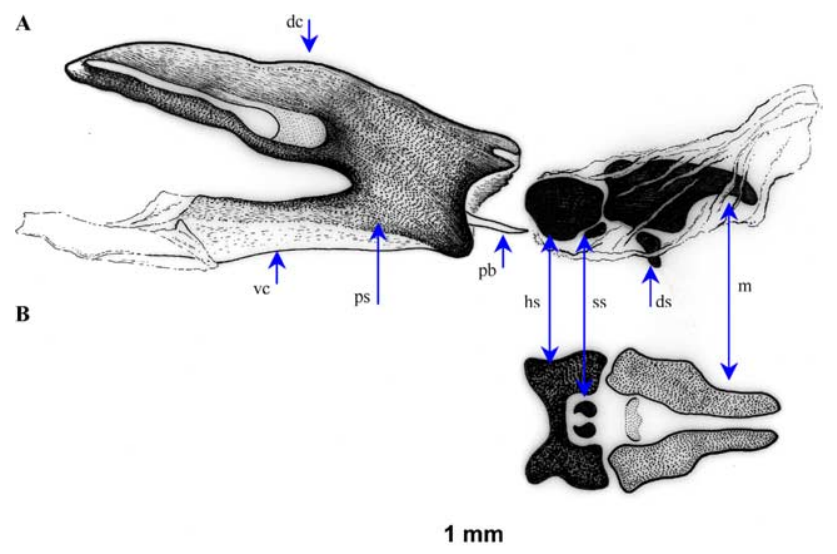

Fig. 5. S. javita cephalopharyngeal skeleton ((A) lateral view, (B) dorsal view); $p b$ : parastomal bar, $d c$ : dorsal cornu, $v c$ : ventral cornu, $d s$ : dental sclerite, ps: pharyngeal sclerite, hs: hypopharyngeal sclerite, ss: subhypostomal sclerite, $m$ : mouthhook. 
Wohlfahrtia, Goniophyto and Ravinia varying from 1 to 8 (Walker, 1937; Maurice et al., 1948; Kano and Sato, 1951; Ishijima, 1967; Ruiz-Martínez et al., 1990). However, the arrangement of the papillae in regular or irregular rows is constant at species level (Table 1) being numerous and disposed in several files in the Japanese species (Kano and Sato, 1951).

It is not possible to establish a clear relationship between the number and distribution of the papillae in the anterior spiracles and the feeding habits (Table 1).

The arrangement of the spinules in the spiracular atrium of S. hirticrus (as far as the outer circumference of the ring of tubercles) is similar to that found in $S$. exuberans (Aspoas, 1991), whereas in S. javita, S. tibialis and $S$. dux (Aspoas, 1991; Sukontason et al., 2003) these spinules are extended only as far as the inner circumference of the ring.

The disposition and shape of the slits on the posterior spiracles as well as the presence of an ecdysial scar are a useful tool in the identification of the Sarcophaginae species (Cantrell, 1981), with these characters being repeatedly described.

Due to the uniformity of morphological structures, many more species would need to be examined before any generic separation could be undertaken on the basis of larval morphology (Cantrell, 1981). However, differences in some characters of 3rd instar larva have been useful in the elaboration of keys at specific levels. The main characters used in the existing keys are: number of papillae in the anterior spiracles; pigmentation, arrangement and hardness of the spinules on the body segments and cephalopharyngeal skeleton (James and Gassner, 1947). Kano and Sato (1951) add the following characters: arrangement of papillae in the anterior spiracles, tubercles on upper border of anal segment, inner projections of peritreme and posterior spiracles (width and height, scar). Ishijima (1967), completes the keys adding: distance between posterior spiracles and morphology of slits. After using SEM, new characters have been incorporated into the species diagnosis: morphology of tubercles on the atrium rim and size of the fleshy projections on the anal segment (Lopes and Leite, 1987); number of rows, orientation and density of spinules in the body segments and spiracular hairs in posterior spiracles (Aspoas, 1991). Awad et al. (2003) take into account new ultrastructure characters: sensillar numbers and types, sizes and locations of the antennal-maxillary sensory complex.

As a general reflection from the preceding compilation and the new data provided in our descriptions, it can be concluded that the most useful morphological characters for diagnosis at specific level are: the structures of both, anterior and posterior spiracles, the morphology of the pseudocephalon (including oral ridges, antenna, maxillary palp, sensilla and ventral organ) as proposed by Kirk-Spriggs (2003) and the morphology and distribution of the spinules and sesilla in the body segments.
The immature stages of other species of Sarcopaga such as Sarcophaga peregrina, S. melanura, S. africa, Sarcophaga misera and $S$. tibialis have been described and related to snails and other feeding sources (Seguy, 1941; Ishijima, 1967; Berner, 1973; Parashar and Rao, 1988; Pérez-Moreno, 2004). Apparently, none of the character states of Sarcophaga larvae and puparia seem to be correlated with particular features of the breeding habits. In order to find a relationship between the feeding site and the larval morphology, similarities between those species should be sought in species with a specific feeding habit. Unfortunately, feeding habits of the genus Sarcophaga are very varied and there are not enough detailed descriptions realised by SEM to reach a conclusion (Table 1).

Kirk-Spriggs (2003) considers that in the case of the necrophagous Sarcophaga namibia Reed, 1974 the extensive overlapping oral ridges of the facial mask are consistent with saprophagy. The same character state occurs in $S$. hirticrus, also a necrophagous species. In this sense, it would be interesting to include the description of the oral ridges in future descriptions.

The early stage characters in other Diptera Cyclorrhapha as Syrphidae, have been informative phylogenetically because their larvae are interpreted to be conservative in evolution (Rotheray and Gilbert, 1999; Pérez-Bañón et al., 2003). The detailed description of early stage morphology in Sarcophaga species using SEM, could also be used in the future together with other character sets such as DNA sequences to estimate Sarcophaga phylogeny.

\section{Uncited references}

Ali-khan, 1974. Barfoot, 1969. Beaver, 1972. Blackith et al., 1928. Coupland and Baker, 1994. Saloña Bordas and Gónzalez-Mora, 2005. Tumrasvin and Kano, 1979.

\section{Acknowledgements}

The authors are deeply grateful to T. Pape for the information provided and his very useful comments. Thanks also to the anonymous referees for their useful suggestions. We thank C. Pérez-Bañón for her help with electron microscopy techniques and A. Martínez-Sánchez for her advices about maintenance of colonies in the laboratory.

Financial support was partially provided by the Spanish Ministerio de Medio Ambiente (No. 040/2002).

\section{References}

Abasa, R.O., 1972. Reproductive biology of Sarcophaga tibialis (Diptera: Sarcophagidae). II. Morphology of external and internal reproductive organs, ovary growth, and oogenesis. Annals of the Entomological Society of America 65 (2), 400-405. 
Ali-khan, F.E.A., 1974. Two cases of human Sarcophaga (Diptera: Sarcophagidae) myiasis in Quebec, with descriptions of the larvae. Canadian Journal of Zoology 52, 643-647.

Aspoas, B.R., 1991. Comparative micromorphology of third instar larvae and the breeding biology of some Afrotropical Sarcophaga (Diptera: Sarcophagidae). Medical and Veterinary Entomology 5, 437-445.

Awad, A., Abdel-Salam, S., El-Ela, R., Abdel-Aal, A., Mohamed, D., 2003. Ultrastructure comparison of the sensory morphology of the first- and third-instar larvae of Parasarcophaga argyrostoma (Robineau-Desvoidy) (Diptera: Sarcophagidae). Egyptian Journal of Biology [Online] $5,148-154$.

Barfoot, S.D., 1969. Sarcophaga nigriventris and S. hirticrus (Diptera: Calliphoridae) both bred from Helix aspersa Müller (Mollusca Helicidae). Entomologist's Monthly Megazine 105, 49.

Beaver, R.A., 1972. Ecological studies on Diptera breeding indead snails. 1. Biology of the species found in Cepaea nemoralis (L.). The Entomologist 105, 41-52.

Berner, L., 1973. Sur le parasitisme des hélicidés par les mouches du genre Sarcophaga. Bulletin du Muséum d'histoire Naturelle de Marseille 33, 87-94.

Blackith, R.M., Blackith, R.E., Pape, T., 1928. Taxonomy and systematics of the taxon Helicophagella Enderlein, 1928 (Diptera: Sarcophagidae), with the description of a new species. Studia Dipterologica 4, 383-434.

Cantrell, B.K., 1981. The immature stages of some Australian Sarcophaginae (Diptera: Sarcophagidae). Journal of the Australian Entomological Society 20, 237-248.

Castillo, M., 2001. Artrópodos presentes en carroña de cerdos en la comarca de la Litera (Huesca). Boletin de la Sociedad Estomatologica Argentina 28, 133-140.

Colwell, D.D., 1989. Scanning electron microscopy of the posterior spiracles of cattle grubs Hypoderma bovis and Hypoderma lineatum. Medical and Veterinary Entomology 3 (4), 391-398.

Colwell, D.D., O'Connor, M., 2000. Scanning electron microscopy of sarcophagid (Diptera) larvae recovered from a case of human cutaneous myiasis. Journal of Medical Entomology 37, 854-859.

Coupland, J.B., Baker, G., 1994. Host distribution, larviposition behaviour and generation time of Sarcophaga penicillata (Diptera: Sarcophagidae), a parasitoid of conical snails. In: Bulletin of entomological Research, vol. 84. pp. 185-189.

Courtney, G.W., Sinclair, B.J., Meier, R., 2000. 1.4. Morphology and terminology of Diptera larvae. In: Papp, L., Darvas, B. (Eds.), Contributions to a Manual of Palaearctic Diptera, vol. 1. Science Herald, Budapest, pp. 85-161. [vi] +7-978 pp.

Dahlem, G.A., 1991. Sarcophagidae (Oestroidea). In: Stehr, F.W. (Ed.), Immature Insects, vol. 2. Kendall/Hunt Publishing Company, Dubuque, IA, pp. 871-873. 975 pp.

Ebejer, M.J., 2000. Description of third instar larva and puparium of Blaesoxipha calliste Pape (Diptera: Sarcophagidae). Studia Dipterologica 7 (1), 121-124.

Hennig, W., 1968. Die Larvenformen der Dipteren, Einebersicht Ber Die Bisher Bekannten Jugendstadien Der Zweiflgeligen Inseckten. 3. Teil. Akademie Verlag, Berlin. [vii] +628 pp.

Ishijima, H., 1967. Revision of the third stage larvae of synanthropic flies of Japan (Diptera: Anthomyiidae, Muscidae, Calliphoridae and Sarcophagidae). Japanese Journal of Sanitary Zoology 18, 47-100.

James, M.T., Gassner, F.X., 1948. The immature stages of the fox maggot, Wohlfahrtia opaca (Coq.). The Journal of Parasitology 33, 241-244.

Kano, R., Tange, H., 1951. Notes on the flies of medical importance in Japan (part II). The larvae of Sarcophaga known in Japan. Japanese Journal of Experimental Medicine 21, 115-131.

Kirk-Spriggs, A.H., 1999. Female, immatures, and hymenopteran parasites of Sarcophaga inzi Curran (Diptera: Sarcophagidae). Cimbebasia 15, 65-70.

Kirk-Spriggs, A.H., 2000. The immature stages of Sarcophaga forceps Blackith and Blackith, 1988 (Diptera: Sarcophagidae), reared from the flesh of a decomposing cowrie shell in Sulawesi, Indonesia. Studia Dipterologica 7 (1), 125-131.

Kirk-Spriggs, A.H., 2003. The immatures stages of Sarcophaga(Liosarcophaga) namibia Reed (Diptera: Sarcophagidae) from the southwestern seaboard of Africa. Cimbebasia 18, 39-47.

Leite, A.C.R., Lopes, H.S., 1987. Second contribution to the knowledge of the larvae of the Raviniini (Diptera, Sarcophagidae) based on observations using scanning electron microscope. Memorias Do Instituto Oswaldo Cruz 82, 219-226.

Lopes, H.S., Leite, A.C.R., 1987. Third contribution to the knowledge of the Raviniini (Diptera, Sarcophagidae), based on observations of the larvae, using scanning electron microscope. Memorias Do Instituto Oswaldo Cruz 82, 407-413.

Maurice, T.J., Gassner, F.X., 1948. The immature stages of the fox maggot Wohlfahrtia opaca (Cog.). The Journal of Parasitology 33, 241-244.

Mendez, J., Pape, T., 2002. Biology and immature stages of Peckia gulo (Fabricius, 1805) (Diptera: Sarcophagidae). Studia Dipterologica 9, 371-374.

Pape, T., 1987. The Sarcophagidae (Diptera) of Fennoscandia and Denmark. Fauna Entomologica Scandinavica 19, 1-203 (2 pl. Leiden and Copenhagen).

Pape, T., 1996. Catalogue of the Sarcophagidae of the world (Insecta: Diptera). Memoirs of Entomology International 8, 1-558.

Pape, T., Gónzalez-Mora, D., Peris, S., 2002. Sarcophagidae. pp. 218-221. In: Catálogo de los Diptera de España, Portugal y Andorra (Insecta). Monografías S.E.A. Miguel Carles-Tolrá Hjorth-Andersen (Coord.), $323 \mathrm{pp}$.

Parashar, B.D., Rao, K.M., 1988. Biological studies of the flesh fly Sarcophaga (Parasarcophaga) misera and its effects as a predator of the snail Indoplanorbis exustus. Entomophaga 33, 431-434.

Pérez-Bañón, C., Rojo, S., Stahls, G., Marcos-García, M.A., 2003. Taxonomy of European Eristalinus (Diptera: Syrphidae) based on larval morphology and molecular data. European Journal of Entomology $100,417-428$.

Pérez-Moreno, S., 2004. Dípteros sarcofágidos (Diptera, Sarcophagidae) relacionados con gasterópodos terrestres (Mollusca, Gastropoda) en ecosistemas mediterráneos. Boletín de la Asociación Española de Entomología 28, 187-205.

Povolny, D., Verves, Y., 1997. The Flesh-Flies of Central Europe (Insecta, Diptera, Sarcophagidae). SpixianaSuppl. 24, 1-260

Rotheray, G.E., Gilbert, F.S., 1999. The phylogeny of palaearctic Syrphidae: evidence from larval stages. Zoological Journal of the Linnaean Society 127, 1-112.

Ruiz-Martínez, I., Soler-Cruz, M.D., Benítez-Rodríguez, R., Díaz-López, M., Pérez-Jiménez, J.M., 1989. Preparation of dipteran larvae for scanning electron microscopy with special reference to myasigen dipteran species. Scanning Microscopy 3, 387-390.

Ruiz-Martínez, I., Soler-Cruz, M.D., Benítez-Rodríguez, R., PérezJiménez, J.M., Adalid-Fuentes, C., Díaz-López, M., 1990. Scanning Electron microscope study of W. magnifica (Schiner,1862) (Diptera: Sarcophagidae). I. Structures with parasitic and possible taxonomic meaning. Scanning Microcopy 4, 103-109.

Saloña Bordas, M.I., Gónzalez-Mora, D, 2005. Primera cita de Liosarcophaga aegyptica (Salem, 1935) (Diptera, Sarcophagidae) de la Península Ibérica, con descripción de sus fases larvarias II y III, pupario y adultos. Boletín Sociedad Entomológica Aragonesa 36, 251-255.

Seguy, E., 1941. Etúdes sur les mouches parasites. 11 Calliphorides. Calliphorides (suite), Sarcophagines et Rhinophorides de l'Europe occidentale et meridionales. Encycl. Ent. 21, 436.

Sukontason, K., Sukontason, K.L., Piangjai, S., 2003. Scanning electron microscopy of third-instar sarcophagid (Diptera: Sarcophagidae) recovered from a mummified human corpse in Thailand. Revista do Instituto de Medicina Tropical de Sao Paulo 45, 95-98. 
(Diptera) parasitando Cebus apella (L., 1758) (Primate: Cebidae) no zoológico de sorocaba, estado de São paulo, Brasil. Entomol. Vect. 11 (2), 317-321.

Walker, E.M., 1937. The larval stages of Wohlfahrtia vigil (Walker). The Journal of the Parasitology 23, 163-174.

Wells, J.D., Pape, T., Sperling, F.A.H., 2001. DNA-based identification and molecular systematics of forensically important Sarcophagidae (Diptera). Journal of Forensic Sciences 46, 1098-1102.

Zumpt, F., 1965. Myasis in Man and Animals in the Old World. Butterworths, London. taxonomic keys (Diptera: Sarcophagidae). Bulletin of Tokyo Medical and Dental University 26, 149-179.

Valle de Sales, K., Hidalgo-Friciello, R., Marinete-Amorim, T., SallesGazêta, G., Serra-Freire, N.M., 2004. Relato de larva de sarcophagidae

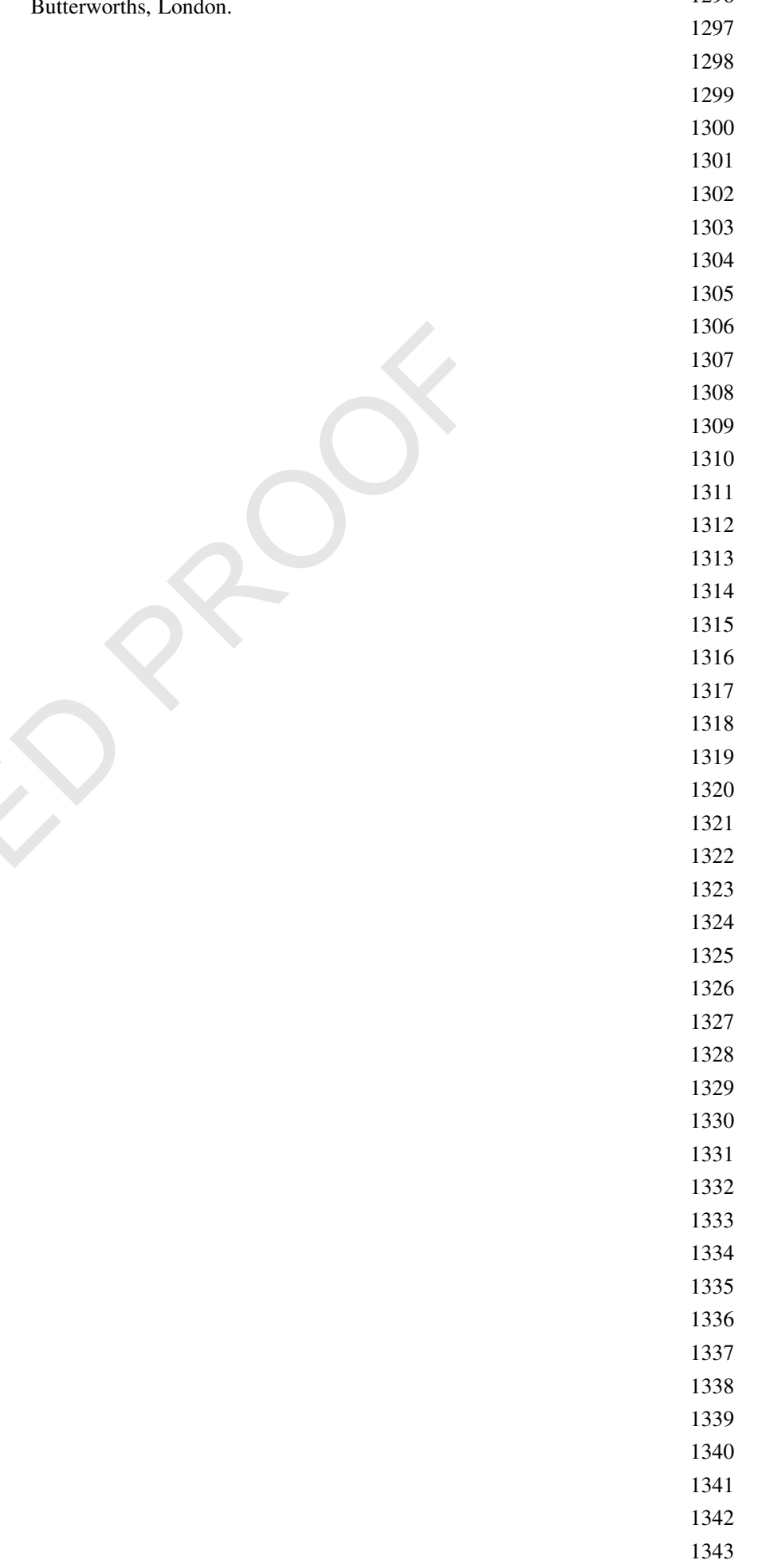

